\title{
Qualified listening and social management among health professionals*
}

\author{
Escuta qualificada e gestão social entre os profissionais de saúde \\ Escuch a calificada y gestion social entre los profesionales de salud
}

\author{
Jader Sebastião Raimundo ${ }^{1}$, Matilde Meire Miranda Cadete ${ }^{2}$
}

\begin{abstract}
Objective: To verify, by means of reports of health professionals, what an institutional program of in-service training must contain that is focused on the development of the capabilities to accomplish qualified listening. Methods: A study using a qualitative, descriptive method, conducted by means of interviews with a focus on the social representations of six professionals - nurses, psychologists, occupational therapists and managers - of an ambulatory clinic at the Hospital das Clínicas de Belo Horizonte (MG), about the procedures of social management in the use of this tool. For analysis of the obtained results, we used an instrument "Collective Subject Discourse". Results: A qualitative study with a focus on the social representations about the procedures of social management in the utilization of this tool. Conclusion: Qualified listening appeared as a management tool to institutionalize transformative work that enables the forwarding of more effective solutions in health care. Keywords: User embracement; Social organization
\end{abstract}

\section{RESUMO}

Objetivo: Verificar por meio de relatos de profissionais da saúde, o que deve conter um programa institucional de formação em serviço voltado ao desenvolvimento das capacidades destes de realizar escutas qualificadas. Métodos: Estudo de abordagem qualitativa, do tipo descritivo, realizado por meio de entrevistas com foco nas representações sociais de seis profissionais - enfermeiros, psicólogos, terapeutas ocupacionais e gestores - de um Ambulatório do Hospital das Clínicas de Belo Horizonte (MG), sobre os procedimentos de gestão social no uso dessa ferramenta. Para análise dos relatos obtidos, foi empregado o instrumento "Discurso do Sujeito Coletivo". Resultados: Estudo qualitativo com enfoque nas representações sociais sobre os procedimentos de gestão social na utilização desta ferramenta. Para análise foi utilizado o instrumento "Discurso do Sujeito Coletivo". Conclusão: A escuta qualificada mostrou-se como uma ferramenta de gestão para institucionalizar um trabalho de transformação que possibilite o encaminhamento de soluções mais eficazes na assistência à saúde.

Descritores: Acolhimento; Organização social

\section{RESUMEN}

Objetivo: Verificar por medio de relatos de profesionales de la salud, lo que debe contener un programa institucional de formación en un servicio volcado al desarrollo de las capacidades de éstos para realizar escuchas calificadas. Métodos: Se trata de un estudio de abordaje cualitativo, de tipo descriptivo, realizado por medio de entrevistas y enfocado en las representaciones sociales de seis profesionales - enfermeros, psicólogos, terapeutas ocupacionales y gestores - de Consultorios Externos del Hospital de las Clínicas de Belo Horizonte (MG), sobre los procedimientos de gestión social en el uso de esa herramienta. Para el análisis de los relatos obtenidos, se empleó el instrumento "Discurso del Sujeto Colectivo". Resultados: El análisis permitió construir tres categorías descriptivas: El significado de escuchar; La comprensión de la escucha calificada; y la gestión social como estrategia del saber hacer. Conclusión: La escucha calificada se mostró como una herramienta de gestión para institucionalizar un trabajo de transformación que haga posible el encaminamiento de soluciones más eficaces en la asistencia a la salud.

Descriptores: Acogimiento; Organización social

\footnotetext{
* Study extracted from dissertation titled "Social management procedures in qualified listening: elements for a program of continuing education in the health service" presented to the University Hospital of Belo Horizonte - Federal University of Minas Gerais - UFMG - Belo Horizonte (MG), Brazil.

1 Master degree in Social Management, Local Development and Education at the University Center UNA, Belo Horizonte; Respiratory Physiotherapist, University Hospital, Federal University of Minas Gerais, Belo Horizonte.

2 PhD in Nursing. Professor of the Master Program in Social Management, Education and Local Development, University Center UNA, Belo Horizonte. NESCONmember-UFMG Belo Horizonte.
} 


\section{INTRODUCTION}

Over time in history, the administration of public affairs and impersonal relationships in healthcare, channeled to the valuation of the disease at the expense of the sick person. From the IX National Health Conference in 1992, the theme humanization has been undergoing discussions, and instituted the National Humanization Policy (NHP) of the Unified Health System (UHS), operationalized through the rescue of the basic fundamentals that guide the practice of health, recognizing managers, workers and users as active subjects and protagonists of health actions ${ }^{(1)}$.

Thus, the NHP has as its main objective, besides other aspects, the possibility of appropriate care and qualified listening of its actors. In this view, the difficulties for the humanization of this system are many, requiring several actions such as: manage the system of co-management; create a health system network; strengthen and upgrade the primary care and enlarge it as a strategy; consider the cultural diversity; overcome the understanding of health as absence of disease; overcome the fragmentation of the labor process and the relationships between different actors; deploy guidelines for welcoming; improve interaction in teams and qualify them; and create a new culture of care, by application of user-centered model in the collective construction of $\mathrm{UHS}^{(1)}$.

In this regard, when dealing with the NHP, the care is mentioned as a guideline in conjunction with the extended clinic, as the following proposed: the obligation to the subject and not with the disease, the recognition of the limits of knowledge with the assertion that the subject is always greater than the proposed diagnosis; affirmation of the clinical encounter between two subjects - health worker and user; the search for balance between the harm and benefits generated by health practices; rely on multi-professional and transdisciplinary teams format of co-responsibility between different subjects and defense of users' rights ${ }^{(2)}$.

Listening and dialogue skills are human beings' features, being common the conception of listening, just as hearing, which can be dangerous, leading to believe that listening is instinctive ${ }^{(3)}$.

In this context, it can be noticed in healthcare professionals and also in the users that the resolution of the cases reported by these may be being compromised by the subjectivity present in each case, since there are evidences that the relationship and communication with them have not been enough or not processed ${ }^{(4,5)}$.

The base document of "UHS Humanization" for managers and UHS workers brings with it that humanization is "appreciation of different subjects involved in the production of health: users, workers and man- agers"()). This is fixed in the values of autonomy and leadership of subjects, among them co-responsibility, solidarity linkages established, users' rights and collective participation in the management process.

The social management as innovation in public health policy and the procedure to be learned constitute a new modality in the management of social policies, which requires flexible and participatory models that involve negotiation and plural participation of a variety of stakeholders involved in decisions and actions into a diversity of policies ${ }^{(7)}$. Thus, the social management is advocated as "a set of tools and strategies for routing solutions for more effective and efficient social policies"(8).

In this sense, this research identifies the components to understanding the construction of the notion of social management as a field of knowledge and practice in NHP of UHS. In this policy, systems of qualified listening work as a management tool to facilitate and institutionalize the work of transforming itself and NHP as a strategy of completeness in the treatment of different disciplines areas of health that affect the same type of problem, ie user-centered care mode.

For social management, the general principle of action which should govern this development approach based on responsible participation of all members of society is an incitement to initiative, teamwork, synergy, but also to self-employment and entrepreneurship.

Nonetheless, when the reality of health unveils low accountability and discontinuity in care and in treatments, a set of problems emerge which represent phenomena of dehumanization: unnecessary queues; neglect and careless with people; inability to cope with life stories, always unique and complex; misplaced ethical practices, such as discrimination, intimidation, submission to unnecessary procedures and practices, charging "extra", exclusion and abandonment, among others ${ }^{(9)}$.

Following this thoughts, it is not about humanizing human, but to confront and deal with power relations, labor and affection, these indeed, produces of dehumanizing practices in relation to our ethical and humanistic horizon. In this conception, humanization is a methodological assertive, a way of doing, handle and intervene to deal with problems of everyday life at the UHS. It is a strategic policy of inclusion of people, collective and social movements leading to the production of changes in the ways to manage and care.

One of the most important principles of NHP is the orientation in the processes of training, ie assume that training is an intervention and that this is training. This assumes the practical experimentation in everyday health services with health teams whose space of excellence for training in health services is the network of $\mathrm{UHS}^{(9)}$. 
In relation to the object of this study which is based on the capabilities of health professionals to perform a qualified listening, this, in addition to other principles of the NHS, they reflect the importance of the training intervention process. Regarding the field of occupational organization, training requires new experimentation and leads to a qualification as continuing health education.

Humanization as proposed intervention in the work processes and the generation of quality healthcare "[...] coincides with the very principles of the UHS, emphasizing the need to provide comprehensive care to the population and strategies to expand the condition rights and citizenship of people"(10).

Given the above, this study aimed to verify, through reports of health professionals, what must include an institutional program of in-service training focused on the development of these capabilities to perform qualified listening.

\section{METHODS}

This qualitative and descriptive study, was anchored in the assumptions of Social Representations, described by Moscovici, which is concerned to elucidating the knowledge-based communication of everyday life, with the intention of guiding practice behaviors in concrete social situations ${ }^{(11)}$. Data collection was conducted through semi-structured interviews conducted individually with four guiding questions for the subject and observing the free expression of their representations. Their statements were recorded after permission of the interviewees. A group of six health professionals participated as subjects, with higher education and members of the multidisciplinary team: nurses, psychologists, occupational therapists and managers.

The setting for this research was the Ambulatory Bias Fortes Hospital of the Federal University of Minas Gerais (ABF-HC-UFMG). This service should be the place where we want to materialize the actions of the NHP with the ultimate aim of community building for care, based on the development of procedural capabilities of health actors to perform qualified listening.

The research project was approved by the Research Ethics Committee of the University Center UNA, and all participants signed a Consent Form. CAAE 0022.0.391.000-10.

For the organization of the data was used the methodological technique of the Discourse of the Collective Subject (DCS) developed by Lefèvre and Lefèvre(12). It is a methodology strategy in order to clarify a given social representation and the set of representations that establish a given imaginary.

For the preparation of the DCS, we started with the speeches in the rough state, which underwent an initial analytical work of decomposition. The work consisted mostly of a selection of the main anchors and/or central ideas present in each individual speeches and all together, ending in summary form, in which it sought discursive reconstitution of social representation. Interviews were registered by a code $(\mathrm{E})$, as follows: $\mathrm{E} 1=$ interview 1, E2 = interview 2 and so on.

\section{RESULTS}

After several readings of the interviews, we searched for the exact location of key expressions, realizing that, on several occasions, some thoughts present on the speech of professionals were in harmony and expressed the heart of the matter that originated this study. At that point, one or more ideas of the expressed thoughts were put together, always worrying with the same fidelity and preservation, grouping them into three thematic categories.

\section{The meaning of listening}

One of the subjects verbalized that listening is "[... solve the need of the other, without judgment," another said that "[...] listening is to give space so that the other can talk." These fragments of speeches first indicate that the health professional provides space for the speaker/user to reveal their thoughts and feelings related to health, needs and concerns ${ }^{(13)}$. Along this same line of thought, there is clarification that the user needs to be heard without interruption, without inferences: simply keep quite, so that their words can be heard ${ }^{(5)}$. These sayings call for the E1 reveals: "[...] I presuppose the recognition of the other," when I hear. This suggests that one must be silent, be quiet, be fully available for the other who says and reveals his/ her world and health status."

In the process of listening to the other, by assuming the provocation of putting own certainties for yourself and passing between to care for the patient's point of view, the ability to foresee other possible dimensions expands. This is the kind of ability one cannot dismiss and it should be taught and exercised on the basis of undergraduate courses in health and in all aspects of interaction and care of human beings.

From the subjects speeches of this research, statements emerged which indicate the "[...] way of listening" as a powerful instrumentation in management, because, as mentioned, "[...] if I am not heard, motivations do not occur ". "[... I think occupational organization depends on listening, in order to have a quality management".

Regarding the operationalization of social management as collective spaces, these have become somewhat and increasingly relevant as organizational arrangements, designed to boost the construction of subjects and collectives organized. In fact, the DCS reveal that 
listening, "[...] is giving this space, so that the other can talk", "[...] listening is a device to belp others."

\section{Understanding of qualified listening on health professionals' point of view}

Qualified listening conceptualized by subjects brings in its wake, its essence, ie it shows adherence to the concepts and assumptions arising from NHP. One can also infer that there are different levels of construction of what is qualified listening: "[...] everyone needs to listen to their patient, in its completeness ... professionals here do not know what qualified listening is "," [...] we are individualistic and selfish because we do not see each other in full. "

At first analysis, it is highlighted the reports concerning the lack of vision of the user as being a whole, evoking thus reflection on the dissociation between qualified listening and completeness. This perspective assumes listening to the others, because the attitude includes the interactive relationship between the health professional and the user, comprising therefore the subject in its completeness by listening to his life story. These statements also showed that one of the doctrines principles of the UHS is not being contemplated in daily care - the completeness.

Therefore, it is also necessary to note, that what is advocated concerning the importance of procedures in social management of the qualified listening systems. Thus, the speech below illustrates this importance: “[... I see it as a management tool that raises awareness, educates and mobilizes all health professionals to a change in behavior."

A qualified listening is designed as a management tool by professionals ".... I understand that it is interactive, collective and social within the work process."

Continuing the analysis, the following Key-expressions demonstrated urgency of reflection: E1 - “[...] care, it is important because it has to be an attitude of all professionals", "[...] it is a process of change of conduct "; E4 -" [...] people lack will to really want that quality, want to change the perspectives of patient care."

Working together, sharing, appreciation of the health professional, active poses/attitudes in labor, the transfer of information and the field of symbolic actions are fundamental principles in current production processes in health. These principles appear in DCS: "[...] I understand as a practice, a skill, a different look, where everyone needs to listen to the patient in their completeness and on the resolution of their condition."

Other DCS that emerged were: "[...] my responsibility increases," and "[...] I think everyone is skilled and competent, but they could improve." Also in the following speech "[...] I presuppose something much broader, it is a part of the care matter and that leads to a real need for training and mobilization" it allows us to think what the authors said about it.

It is also explicit in the following DCS: "[...] the hos- pital needs to systematize and organize it to a qualified service and social improvement of the individual." Thus, it is evident by reports that the duration of meetings and critical dialogues between knowledge and practice through team meetings, workshops, research and analysis activities, are able to achieve this quality care - the reconstruction on the way people think and act.

\section{Social management procedures as a strategic plan for the know-how}

In this context, knowing how to do a qualified listening refers to skills that define the dimensions of competence. These skills, expected from health professionals to obtain a directed and productive performance on the application of knowledge in question. The following DCS confirm this observation: "[... I think the training has to go through the awareness process of the professional." ".... It has two stages, one in which is the reflection (discussion), that is more subjective, and the skill that one has to develop to expose their weaknesses "and" [...] I think there's a need for bumanistic, participatory and organized training, leading to changes in the work process."

It was also verified through the DCSs that the urgency to implement structural reforms in the ABFHC-UFMG in relation to its operating model, especially in the reconstruction of the way people think and act: "[... I believe that this research will teach people what qualified listening is, because everyone needs to figure it out "," [...] We need to develop values like simplicity, honesty and motivation to assume goals."

In fact, according to the central idea of E5, "[...] they are doing co-management and become subjects of collective construction process and must be legitimized by the manager."

The statement confirms the key-expression put into the central idea of the DCS E1: "[...] I see the process of change by caring, such as continuing education and must come guaranteed by the evaluation." The important thing here is the know-how together, supporting experiences, adding knowledge with the transformation of reality: "[...] I think people should be able to select the theme and subject them to a group dynamic" and "[...] the institutional supporter systematizes the information in the process."

Other speeches accentuated the group dynamic or the workshops or as a way to go to the training of professionals: "[...] I propose group dynamics with elements of teams that are more sensitive to a qualified service ... in order to use these qualities in favor of the completeness";" [...] I think the group dynamics (workshops) by discussing the listening will go through the communication and at the same time promote bumanized interaction."

Most participants reinforced the importance and need for training as an essential tool in the development of performing qualified listening as a management tool to trigger systematized actions of care. For example, E1 
contributed to his perception: "[...] I think the training would be ideal to sensitize others [...];" for E3, "[...] I suggest a care training because you learn more when listening" and as E4, " [...] I see the need for a group coordinating and evaluating the sensitiveness workshops."

Therefore, the subjects reported qualified listening as being a must do, both for users and workers, propose goals and develop specific indicators that meet institutional demands, which was implicit in DCS: "[... I I can also link it all with the tools of quality management, which is a collective ongoing process, and that takes time to get a change of culture."

\section{DISCUSSION}

When analyzing the interviews, it was identified that listening transcends hearing, because there are not only the words that penetrate our being, but all sense put on them by the speaker ${ }^{(14)}$. Complementing, the completeness of the person is done through its "active listening", when objectively listening through their verbal and nonverbal language and their subjectivity unveiled relationships built with health professionals ${ }^{(15)}$.

Completeness is understood as refusal to reductionism and objectification of the subject and the affirmation of opening statement for dialogue ${ }^{(16)}$. Based on this concept, it is understood that a qualified listening is an essential tool for the user to be answered from the perspective of care as integral action, since, through it, you can build links, production of care relations, respect for diversity and uniqueness in the encounter between the caregiver and the care recipient.

In this sense, supported by two authors ${ }^{(17)}$, it appears to be possible to pursue a quality management when the manager has features like comprehensive vision, ethical orientation, sensitivity and communication skills and articulation. These features allow the manager to know the institution, people of his/her workgroup and thus may promote the development of both. One can infer that this will only happen if he/she indeed perform a qualified listening.

In this research, speeches analyzed pointed intervention in the area of social management in healthcare, by focusing on the urgent need to reflect on the values assumed in the territory of micro decisions during the course of action and understanding of practice and subjectivity of health professionals and the dynamism of the organization of the work process ${ }^{(8)}$. Managing social health through qualified listening enables dialogue between people, so that the interaction occurs and the collective is present.

There is agreement about the concrete spaces dedicated to listening and the traffic of information relating to desires, interests and details of reality, as well as the analysis of listening and processing the information and subsequent decision making ${ }^{(18)}$. These collective spaces are instruments that can turn into working groups and co-management, as units of health production, and through participatory management create bonds of solidarity and collective participation with all actors in health care, ensuring quality people management ${ }^{(19)}$.

It must be recognized that the negotiation of "use of self" is always a "dramatic" place, that is, the work is always a drama that involves the health worker as a completeness, it is the space of tensions and problematic negotiation of norms and values. Reflecting on the management and competency assessment in the workplace, also insists that any approach that thought is legitimate and useful ${ }^{(20)}$.

Statements reiterate on transparency, ethics, respect and social responsibility as social management procedures that should nourish the actions of health professionals ${ }^{(21)}$. One can also say that the actors in the process of qualified listening in social management, need to understand that in giving answers, the team need to keep in mind that solutions are not only up to the team, but they are the responsibility of all the institution.

The challenge is put, it is necessary to want to change the way people listen, communication, and how they are embedded in relations between professionals and users. If this communication is not conducted effectively, the voices of all social actors in the health area will be inaudible and may incur consequently suffering. It can be seen here the importance of care, the construction of projects of collective ambience, the boards of management with the participation of all in making decisions and in activities of health training and work ${ }^{(22)}$.

These activities should be guided by the paradigm of permanent education ${ }^{(21)}$ and that, based on relational management, it is possible that new relationship among workers from $\mathrm{ABF}$ arise. From this point of view, it is worth mentioning what has been explicit about the social management of the clinic. Not always actions show the meanings of know-how and knowledge to relate through a shared strategic plan: the organization management ${ }^{(23)}$. Advancing this thinking, it adds that social management happens through the actions of health professionals that discuss, reflect and share their daily experiences on a constant seek to learn ${ }^{(24)}$.

The representations involved in the testimonies of health professionals not only reflect the principles of common sense, but they are also organized on the basis of their learning and their own reflections on the scientific knowledge. From the many speeches of the subjects in this study emerged sayings concerning, for example, procedural content, ie, referring to a set of "know-how"(25). 
Thus, it was noted that DCS are embedded in the central principles and concepts to the NHP, as: transversality, worker valorization, autonomy and leadership, strengthening teamwork, shared responsibility, establishing links of solidarity and collective participation, supporting the inseparability of care and management ${ }^{(26)}$.

In this regard, it is worth remembering that the ambience of quality favors relational and communicational dimension important for the formation of new subjects, freer, more creative, more compassionate, more capable to move from immediate interests ${ }^{(27)}$.

In this sense, social management would have the ability to produce better subject, more capable of withstanding the existence in more heterogeneous landscapes, in which the expression of the human, as social and political force are more diverse ${ }^{(9)}$.

The NHP, as a method of inclusion manifests itself here as an alternative ethical and political performance on the possibility of producing changes in $\mathrm{ABF}$, since the inclusion of its professionals in the processes of interpretation and analysis of the entire organizational context as well as the intervention becomes necessary.

Through the interviews, it was found to be necessary to learn to do many things and the ABF should be taught to do them. It was also verified that learning from them and teach them requires consideration of the specific nature of procedural content, which behave in a certain way, to understand the educational intervention which aims to encourage and assist in the learning process of health professionals in the use of social management systems in qualified listening to the collective construction of care.

Based on the research performed, we can conclude that the procedures for managing social health, here specifically the qualified listening tool, refer to the skills, abilities, and knowledge to pose/attitudes essential for effective functional and organizational of ABF. These include in particular the training gaps that contribute to valuable information in collaborative decision making, and a new strategic alignment and delimitation of action plans.

In this context, we highlight the role of the nurse whose social practice is seen as being integrative of health actions not only for their ability to understand the social context, but the ability to interact directly with the user, family, community and staff health ${ }^{(28)}$.

In this sense, the challenge here is not only to appropriate this device, but understand it and use it as a powerful tool of social management in health ${ }^{(27)}$.

\section{FINAL CONSIDERATIONS}

The subjects of this research had some knowledge regarding the attributes/skills of qualified listening and were aware that these increase the technical skills of health workers in order to promote humanized interaction, citizenship and solidarity (also these procedures are social management), with users, family, community. Recognized also that the qualified listening is a sine qua non condition for effective ethical and political in relation not only to the health problems of acute or chronic nature, but also to effect the policies of UHS.

In this study, we identified some social management procedures in qualified listening according to the NHP, as: listening actions and bond production of therapeutic activity ; ways of organizing health services, the use or otherwise of knowledge and affection for improving the quality of health and how these knowledge and affections are for life; humanization of relations in service, the ambience and the adequacy of compatibility between supply and demand for health actions; governance of local teams and existing forms of management in the health unit. It is evident, therefore, that these findings may stimulate professional reflections that trigger new thinking and acting every day.

The results showed also that the systematization of social management procedures in qualified listening are indispensable tools for decision making regarding the definition of clinical social management, in obtaining institutional investment, such as training for the sector in monitoring the humanization of health, in assessing the impact of management and quality of services.

Therefore, these results may support changes in ABF-based discussion among all professionals that comprises the health care team that works there, turning the difficulties and weaknesses relevant to listening, care and management in substrates for reflection and changes that may optimize the resources of all kinds in the $\mathrm{ABF}$.

In this direction, the training of the actors involved in the production of health conduct social management more participatory and inclusive, adapting the service to the local cultural and social environment through the health care, as recommended by the NHP.

Finally, we recognize the need for future studies, since the qualified listening and social management; discussions require larger theoretical support for its development and implementation in the care process. 


\section{REFERENCES}

1. Brasil. Ministério da Saúde. Humanização e ampliação (PNH) [nternet]. 2006 [citado 2010 Jan 29]. Disponível em:http://portalsaude. gov.br/portal/saude/visualizar_texto.cfm? idtxt=27147.

2. Brasil. Ministério da Saúde. Secretaria de Atenção a Saúde. Núcleo Técnico da Política Nacional de Humanização. Acolhimento nas práticas de produção de saúde. 2a ed. Brasília(DF): Ministério da Saúde; 2006. (Série B. Textos Básicos de Saúde).

3. Burley-Allen M. The Listening: the forgotten skill. A selfteaching guide. New York: John Wiley \& Sons; 1995. What is listening and what can it do for you?; p. 1-13.

4. Ceccim RB. [Permanent education in the healthcare field: an ambitious and necessary challenge].Interface (Botucatu). 2005; 9 (16):161-77. Portuguese.

5. Mariotti H. Pensamento complexo: suas aplicações à liderança, à aprendizagem e ao desenvolvimento sustentável. São Paulo: Atlas; 2007.

6. Brasil. Ministério da Saúde. Política Nacional de Humanização (PNH). Documento base para gestores e trabalhadores do SUS. Brasília(DF): Ministério da Saúde; 2008.

7. Fidalgo FS, Machado LR. Dicionário da educação profissional. Belo Horizonte: Núcleo de Estudos sobre Trabalho e Educação; 2000.

8. Lobato LV. Gestão social: contribuições para o debate teórico sobre o campo. Rio de Janeiro: Cebes; 2008.

9. Pasche DF. Humanizar a formação para humanizar o SUS. Apresentado no $1^{\circ}$ Seminário Nacional do Pró-Saúde II. Coord. PNH e Gestão do SUS/MS. Brasília, 2009.

10. Santos-Filho SB. [Perspectives of the evaluation of Brazil's National Health Humanization Policy: conceptual and methodological aspects] Ciênc Saúde Coletiva. 2007; 12(4): 999-1010. Portuguese.

11. Moscovici S. Representações sociais: investigações em psicologia social. Guareschi PA, tradutor. 6a ed. Petrópolis: Vozes; 2009.

12. Lefèvre F, Lefèvre AM. O discurso do sujeito coletivo: um novo enfoque em pesquisa qualitativa (desdobramentos). $2 \mathrm{a}$ ed. Caxias do Sul:Educs; 2005.

13 .Gonçalves RL. Práticas de integralidade: acolhimento e vínculo no cuidado prestado a gestante [dissertação] Recife: Fundação Oswaldo Cruz; 2009.

14. Brasil. Ministério da Saúde. Secretaria de Atenção à Saúde. Departamento de Ações Programáticas e Estratégicas. Atenção hospitalar. Brasília: Ministério da Sáude; 2011. (Série B. Textos Básicos de Saúde; Cadernos Humaniza SUS, v. 3).

15. Filgueiras SL, Deslandes SF. [Evaluation of counseling activities: analysis of a person-centered prevention perspective] . Cad Saúde Pública.1999; 15 (Supll 2):121-31. Portuguese.

16. Fischer T, Melo VP. Programa de desenvolvimento e gestão social: uma construção coletiva. In: Fischer T, Roesch S, Melo VP, editores. Gestão do desenvolvimento territorial e residência social: casos para ensino. Salvador: EDUFBA, CIAGS/UFBA, 2006. p.13-41.

17. Moraes MC, Torre S. Sentir Pensar, fundamentos e estratégias para reencantar a educação. Petrópolis(RJ) Editora Vozes; 2004.

18. Mattos R A. Os sentidos da integralidade: algumas reflexões acerca de valores que merecem ser defendidos. In: Pinheiro $\mathrm{R}$, Mattos R A, editores Os sentidos da integralidade na atenção e no cuidado à saúde. Rio de Janeiro (RJ) Editora UERJ, IMS - ABRASCO, 2001. p. 113-126.

19. Schwartz Y. Os ingredientes da competência: um exercício necessário para uma questão insolúvel. Educ Soc.1998; 19(65):101-40.

20. Colen J. Ouvidoria pública de saúde de Belo Horizonte. Saúde on line [internet]. 2008; 24. [citado 2012 out 9]. Disponível em: http:/ / www.pbh.gov.br/smsa/saudeonline/ index_interna.php?cod=94.

21. Schommer PC,França Filho GC. A metodologia da residência social e a aprendizagem em comunidades de prática. In: Fischer T, Roesch S, Melo VP,editores.Gestão do desenvolvimento territorial e residência social: casos para ensino. Salvador (BA):EDUFBA, CIAGS/UFBA; 2006.

22. Macedo RG. A democratização da informação na gestão pública: a cibercomunicação como ferramental estratégico no tratamento da informação. In: $30^{\circ}$ Congresso Brasileiro de Ciências da Comunicação; 2007 Ago 29-Set 02; Santos; 2007.

23. Ferrara LF. Design em espaços. São Paulo: Rosari; 2002.

24. Boullosa R, Schommer PC. Limites da natureza da inovação ou qual o futuro da gestão social? In: XXXII ENANPAD - Encontro Nacional de Pós-Graduação e Pesquisa em Administração; 2008 Set 6-19; Rio de Janeiro; 2008.

25. Zabala A. Como trabalhar os conteúdos procedimentais em aula. 2a ed. Porto Alegre: Artmed; 2007.

26. Santos-Filho SB, Barros MEB. Trabalhador da saúde muito prazer! Protagonismo dos trabalhadores na gestão do trabalho em saúde. Ijuí: Unijuí; 2007.

27. Tenório FG, organizador. Gestão social: metodologia e casos. 3a ed. Rio de Janeiro: FGV; 2002.

28. Girondi JB, Hames ML. [The process of nursing care according to post-modern sociological paradigm]. Acta Paul Enferm. 2007; 20(3);368-372.Portuguese. 